\title{
Human Resource Practices in the Informal Sector in Cape Coast, Ghana
}

\author{
Antoinette C. Kumi-Kyereme \\ Outsource HR Person \\ P. O. Box NB 1109, Accra, Ghana \\ Tel. 233-277 455883 E-mail: outsourcehrperson@yahoo.com
}

\author{
Francis O. Boachie-Mensah (Corresponding author) \\ School of Business, University of Cape Coast \\ University Post Office, Cape Coast, Ghana \\ Tel. 233-332136435 E-mail: fbmens2002@yahoo.co.uk
}

Received: December 12, 2011 Accepted: January 1, 2012 Published: January 1, 2012

doi:10.5296/jmr.v4i1.1160～URL: http://dx.doi.org/10.5296/jmr.v4i1.1160

\begin{abstract}
The human resource is the most productive of all resources, the most versatile, and the most resourceful. Thus an enterprise's wealth does not depend on the financial and material resources available but rather on the people who make things work. It is therefore important for owners and managers of firms to understand how best to manage this most resourceful human resource - of the firm. This study examined the human resource practices in the informal sector in Ghana, using the situation in the Cape Coast Metropolis as a case study. The main objective of the study was to find out how the human resources within the informal economy were being managed. Six major informal sector operators were randomly selected. A combination of cluster sampling and quota sampling techniques were applied to generate the sample for the study. The total sample for the study was one hundred and seventy. The results of the study show that human resource management practices within the informal sector enterprises are inadequate and therefore impede the development of the workforce which invariably affects the growth of the enterprises. The findings suggest that assistance programmes that encourage the efficient and effective human resource management practices in the informal sector should be provided. The main limitation of the study is that it could not
\end{abstract}




\section{Macrothink

cover all informal sector enterprises within the metropolis due to time and financial constraints. In this respect, the interpretation of the results of the study should not be over-generalised.

Keywords: Human resource management, Informal sector, Entrepreneurs, Social security, Labour turnover, Motivational factors 


\section{Introduction}

According to Drucker (1982: 262), the human resource (HR) is of all resources the most productive, the most versatile, and the most resourceful. Thus an enterprise's wealth does not depend on the financial and material resources available but rather on the people who make things work. Researchers with an interest in human resource management (HRM) have often limited their research to large firms (Storey, 1992). However, observers have recently called for more work analysing human resource issues within small and medium-sized businesses (Purcell, 1993). While smaller employers may be interested in tracking developments in larger organisations, it should not be assumed that practices used by large firms are necessarily beneficial or practical for smaller businesses.

While success and failure in small businesses are often predicted using financial criteria, Marlow and Patton (1993) submit that the effective management of employees is also emerging as a key variable in the survival of small firms. They argue that small firms often do not employ professional experts to manage human resource issues, are considerably less likely to be unionized, vary markedly with regard to the provision of training, and often do not engage in strategic employee management with the goal of gaining competitive advantage. Holt (1993) states that a firm needs a well-motivated, skilled workforce if it is to compete effectively in the global marketplace, and there is growing empirical evidence linking HRM activities and organisational performance (Becker \& Gethart, 1996; Ichniowski et al, 1996). While large organisations are undergoing massive downsizings and employee cutbacks (Cascio, 1993; Cameron, 1994), recruiting and keeping good employees represents a major challenge for many informal small firms (Hornsby \& Kuratco, 1990; Mathis \& Jackson, 1991).

Informal sector activities have become a major component of survival strategies adopted by most households, like in other economies, in Ghana in general and in Cape Coast in particular in order to cope with declining welfare and wages. In recent times, there has been a proliferation of economic activities in trading of all kinds, with incomes in most households being supplemented from some form of informal sector activity. However, there seems to be a paucity of credible data on HRM practices in the Ghanaian informal sector, making it difficult to carve appropriate management interventions to address the problem because the exact dimensions of the challenge are not known. Literature on the informal economy in general is replete with information on its nature or classification, origin, size, mode of entry and even difficulties arising due to its ambiguity (Justice, 2002), yet little information exists on how employees within the informal economy are managed. In fact, it is difficult to find reliable information about those who work in the informal economy. It is even more difficult to pinpoint their problems relating to occupational safety and health, wage administration, employment relations and decent work (Salter, 2002). It is against this backdrop that this study sought to assess the HR practices within the informal sector in the Cape Coast metropolis. The main objective was to determine how the human resources within the informal economy were being managed. The study sought to draw out the dimensions of HR practice and employee management within the informal economy. It focused on the traditional role and practice of human resource management (HRM), specifically on 
recruitment and selection, training, health and safety, employee motivation and retention, and employee termination; and how these are practiced within the informal economy. It was expected that the results of the study would contribute to filling existing research gaps and to help formulate appropriate policies that will regulate HRM practices within the informal sector of the economy.

\section{Literature Review}

Literature on the informal economy in general is replete with information on its nature or classification, origin size, mode of entry and even difficulties arising due to its ambiguity (Justice, 2002), yet little information exists on how employees within this economy are managed. In fact, it is difficult to find reliable information about those who work in the informal economy; it is even more difficult to pinpoint their problems relating to occupational safety and health, wage administration, employment relations and decent work (Salter, 2002).

\subsection{Working Conditions}

Informal sector operators function from clusters close to cities, especially those engaged in auto repairs, metal works, etc., but may also be strategically located at specific points to reach the maximum number of clients. Working conditions are very poor due to the insecurity the entrepreneurs experience with respect to their premises (Barwa, 1995:8). According to Yankson (1992), 85\% operated from permanent premises which were actually their residences while the rest worked in temporary sheds and structures usually under trees or open spaces. Thus, while food processing ('chop bars') operated from home, handicrafts and sandcrete manufacturing units operated under trees or open spaces. This explains their general poor access to utilities, like water and electricity. Furthermore, they are under continuous threat of eviction (Barwa, 1995). The working conditions in the sector are rather poor due to the insecurity which entrepreneurs experience with respect to their premises (Yankson, 1992:16)

Informal employment recruits people of all backgrounds and all levels of education and qualification. Many formally employed persons also hold informal jobs. Along with formal jobs in public services, many employees have small backyard gardens to subsidize salaries and feed their families. In rural areas, micro-farm agriculture for the local market and subsistence agriculture have played an important role in many families' survival since the economic recovery programme changes in the early 1980s. People with higher education who are employed in public services at very low pay are typical multiple jobholders as well as those who were made redundant after organisational reforms can be found actively engaged in the informal sector. While they naturally prefer to stay in their qualifications and professions, as private tutors, for example, they also take any other job: peasants, traders, shop assistants (Finnegan, 2000).

\subsection{Nature of work and workers in the informal sector}

Informal employment can take place in all sizes of enterprises and all possible workplaces. Home-based workers, with or without registered self-employment, offer services in 
crafts/trades as well as jobs that require higher education. Such workers sell products or render services to friends, neighbours, relatives or wider communities in cities. They have workshops within or near their homes and are often subcontracted. Many are former qualified or other academically educated workers.

Informality can include all varieties of absence of protection, circumvention of laws and levels of labour insecurity. Particularly, informality appears as absence of labour contracts and collective bargaining agreements, extreme wage flexibility, seasonal or hired employment, child labour, leave granted not according to the law or refused arbitrarily, excessive hours, unpaid or improperly paid overtime, wages below a living scale, etc. Such conditions include poor occupational health and safety standards, little, if any, job security, no access to state social security and free social services, no education or training, no social mobility, and a high economic and personal dependency on employers (Tesselaar, 1998).

Non-home-based enterprises can be registered, but social security contributions might not be paid. A frequent feature of informality in these work arrangements is the joint understanding between employers and employees about avoiding the employer's legal requirements (registration, payment of social contributions, etc.) under the constant threat of lower wages, weakened work standards or dismissal. This joint understanding is both voluntary and forced on the part of the employees; voluntary because employees can say no but have to be aware of the negative consequences (Musiolek, 2002).

Informal employment in the country can be seasonal, hired or contract labour - sometimes even on a daily basis - for instance, weeding, washing cars, or construction. Many seasonal, contract or hired workers are migrant labourers, such as people from tother parts of the country; and migrants from other West African and/or African countries. Many of them do not have legal residence status in the host countries (Yankson, 1992).

\subsection{Welfare, Health and Safety}

In his report to the ILO on International Occupational Safety and Health Programme on the Informal Sector within the Philippines, Salter (2002) stated that very often much of the work within the informal sector takes place in unhealthy conditions, such as working in small, unventilated and not well lighted shops. This reduces productivity, which adversely affects the profitability and indeed the viability of the enterprises. He stated further that informal sector operators and workers may not even be registered with the appropriate safety regulatory authorities. They may also be imperfectly covered in the national statistical collections such as labour surveys. Since few informal sector workers are covered by social security, and especially by workers' compensation, the information on occupational accidents and diseases that is collected as a result of claims ignores these workers.

In a report by the ILO, the consequences (of working in the informal sector) are often devastating with awful pay and safety regulations, job insecurity and a total lack of representation. The precarious nature of work in the informal sector results in the low earnings of the workers. Informal workers commonly endure poor working and employment conditions, including long working hours, physically difficult and uncomfortable conditions, 
risk of fire and accidents, low and irregular incomes, lack of maternity protection, and risk of harassment and violence. They lack access to services and tools that would empower them to make improvements (ILO, 2003). According to a related study conducted for the ILO by Wanjek (2005), how workers eat while at work is not always given much thought. The main concerns of employers and trade unions seem to be safety, wages and job security. The study demonstrates that good nutrition at work is good business, leading to gains in productivity and worker morale and reductions in health-care costs.

\subsection{Labour Regulations, Leave and Rest Hours}

Labour regulations within the informal economy are non-existent. According to Lagos (1992), complying with labour regulations is a substantial fixed burden for firms. Thus it is more onerous for lower income-earning firms to comply with labour regulations as it pertains within the formal sector. A study conducted in Brazil on employment practices within the informal sector showed that about $27.5 \%$ of the labour costs, which should be supported by the employer on behalf of the employee, are in taxes plus the indirect benefits (e.g. contribution to social security, 30 days of paid holidays per year, maternity and annual paid leave). Therefore, in a bid to escape these extra labour costs associated with the formal sector, it was an incentive to the employer to hire informally, where most of these benefits are negotiated on a case-by-case basis between the employer and the employee (and sometimes not paid). Moreover, unregistered informal workers do not have access to unemployment benefits and severance payments (Soares, 2005).

As Almeida (2004) points out, informality may leave the poorest workers in the economy in a very vulnerable position, since they cannot benefit from the social protection regulations established by the governments of their countries. This is a major source of preoccupation since workers in the informal economy in many cases are poor and low skilled and work in precarious conditions. Therefore, poor workers are able to find employment which they might not have been able to find otherwise, although they cannot benefit from basic social protection. According to Hansenne (1991), informal economy workers are therefore vulnerable due to the fact that, to a large extent, they operate beyond the law (not illegal but not officially registered), and receive little or no legal protection. This deprives them of the right to appeal to the courts for contracts to be enforced or to claim security of tenure.

\subsection{Social Security Benefits, Incomes and Earnings}

Research carried out on the characteristics of the informal economy (Ninsin, 1991) has shown that although the informal economy can adapt to policy stimuli much faster than the formal sector (because of its ease in setting up and exit), it has considerable limitations. One of the limitations of the informal economy is its capacity to provide paid employment. Earnings vary between operators in different activities, but often are very low, resulting in workers finding it difficult to save for periods of illness or injury. Their ability to benefit from national social insurance, such as health care, is dependent upon the firm being part of the formal economy and on the employer paying contributions into these schemes (ILO, 2003). 
In her work on the informal economy, del Castillo (1984) states that informal employment is characterised by at least partial precariousness such as the absence of one or several characteristics of 'typical' employment, which are: salaried, sustainable, stable, full-time job, allowing for a career, providing the main family revenue, under one employer, individually assigned and carried out at a specific work place. However, workers themselves sometimes want to work on the fringes of the law, either because, for them, it is the only way to have employment, or because they see in it a short term advantage (higher salary because they are not burdened with social security contributions). But as soon as workplace accident occurs, or when they are prevented from working, or still during maternity leave, they are deprived of all replacement income, even of all rights (World Confederation of Labour, 2002).

\subsection{Training}

In his work on the informal sector, de Soto (1986) put forward that development agencies in Less Developed Countries (LDCs) generally focus on the positive assessments of the informal sector by providing credit and training. Their goal is to promote the growth of individual firms within the sector while ignoring the question of whether they may be inadvertently creating more exploitation and social problems as these unregulated or semi-regulated firms violate labour relations laws of safety, health and environmental regulations.

In his work on employment practices within the informal sector, Yankson (1992) states that most of the informal sector entrepreneurs have little or no formal training apart from the apprenticeship exposure which results in the apprentices being used. In addition to the fact that apprentices are 'used' and have 'no certain income', Baah-Nuakoh (2003) maintains further that the effectiveness of the training is limited to the knowledge of the "master". He states that the 'level of technical knowledge within the sector is limited to what is passed on from the master to the apprentice by repeated exercise, and this does not include the mechanisms behind the operation of the machines. Unlike the formal sector, where training builds on the infusion of new skills, ideas and managerial ability on the part of the trainee, a major limitation of the process of skill transmission in the informal sector is the lack of managerial skills on the part of the craftsmen, which in turn impedes the possible transformation of the informal sector firms to modern formal ones (Baah-Nuakoh, 2003:83). According to Yankson (1992:24), the level of education and training has an important bearing on the entrepreneurs' ability to absorb managerial and technical information, as well as the ability to enhance productivity and production. It is also important in the entrepreneur's access to and the understanding of official regulations and how they affect the enterprise, as well as his ability to have access to official assistance such as credit and other facilities.

\subsection{Labour Turnover and Employee Dismissal}

Labour is relatively unstable in the informal sector as compared with the formal. On the average, duration of stay of most workers in the informal sector is between 1 and 4 years (Yankson, 1992). This is also the usual period of acquiring skills in most trades. 


\section{Macrothink Institute ${ }^{\text {TM }}$}

Based on the extant literature and the contributions by various authors and research context, the study was guided by the following research questions:

- What procedures regulate the recruitment of human resources into the informal economy?

- What programmes or procedures are in place regarding the welfare, health and safety of employees?

- What training activities exist and how this impacts on the knowledge, skills and abilities of employees?

- What measures exist to motivate and retain employees within the enterprise?

- Are there any social security benefits/contributions paid on behalf of the employees?

- How do employees exit the sector?

\section{Methodology}

The study design adopted was descriptive and analytical based on cluster sampling technique. This was chosen in view of the fact that this was a small-scale study of a relatively short duration, which involved a systematic collection and presentation of data to give a clear picture of how people were managed within the informal sector enterprises. The target population consisted of workers within the informal sector located within the Cape Coast Metropolis. Specifically, it comprised steamed fermented corn dough ('kenkey') producers; wayside fitting shops (auto mechanics); food vendors (table top and 'chop bar' operators); palm kernel oil producers; roasted milled cassava ('gari') producers; petty traders; fish smokers/processors and dressmakers. A sample of 170 respondents was selected from the various identifiable groups. The sample unit was based on the following criteria: enterprises which have been in existence for more than 3-years and enterprises which have had more than 4 workers (working continuously within the past 1-year).

A structured questionnaire was used to collect data from respondents, which was administered personally by the researchers in order to gain a thorough understanding of and to get first hand information about the problem under study. After all the necessary data was collected, edited and coded, relationships and other associations were determined, using descriptive analysis and the formulation of tables, graphs and other descriptive analytical methods. Percentages and other statistical methods were used to analyse the data and conclusions were drawn on the results obtained.

\section{Discussion of Findings}

In order to gain insight into HRM practices within firms in the informal sector, the main dimensions of their approach to employee management were sought.

\subsection{Welfare, Health and Safety}

The study discovered that most of the workplaces did not have adequate equipment or structures in place to safeguard the health of the workers. The food vendors, gari 
processors, palm kernel oil processors and the fish processing group all use large open fires in their operations. None of them have buckets of sand or anything handy as a safety measure to use immediately in case of a fire outbreak.

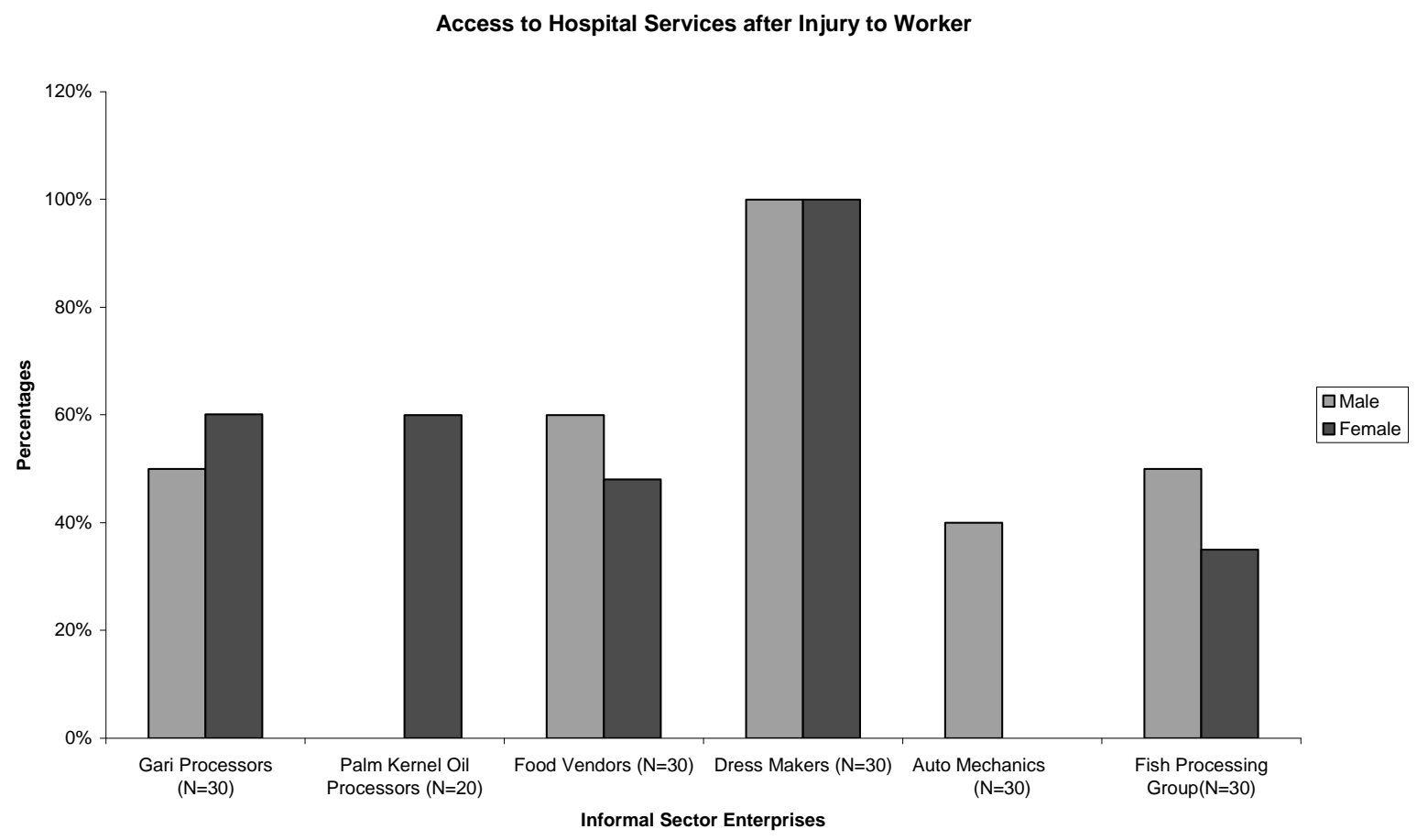

Figure 1. Access to hospital services after injury to the worker on the job

The data showed the availability of some forms of first aid kit, accessibility to hospital facilities and/or services after injury at the workplace. Rest periods are taken during normal working hours among the major groups of workers interviewed. Compensation is paid to workers after injury at the workplace; hospital bills are settled by the employer and any other treatment is given when injured at the workplace. Out of 28 female gari processors within the Duakor area of the Cape Coast Metropolis, 35\% of them had access to hospital services when injured on the job. These figures are represented in Figure 1.

This means that the rest (65\%) are not taken to the hospital for treatment. This could mean that when employees are injured on the job the hospital is always not the first option for them. They are either treated in the house or sent to a nearby drugstore. This corroborates the findings of studies conducted by Salter (2002) on health and safety within informal sector enterprises. His study showed that informal sector employees lack access to proper medical care when injured on the job. According to Tesselaar (1998), informal sector workers have no access to state medical services. The inability of workers gaining access to hospital services when injured on the job is confirmed by an ILO publication on decent work, which states that the 'ability of workers to benefit from national social insurance, such as health care, is dependent upon the firm being part of the formal economy', of which most of the informal sector enterprises in Ghana are not. 


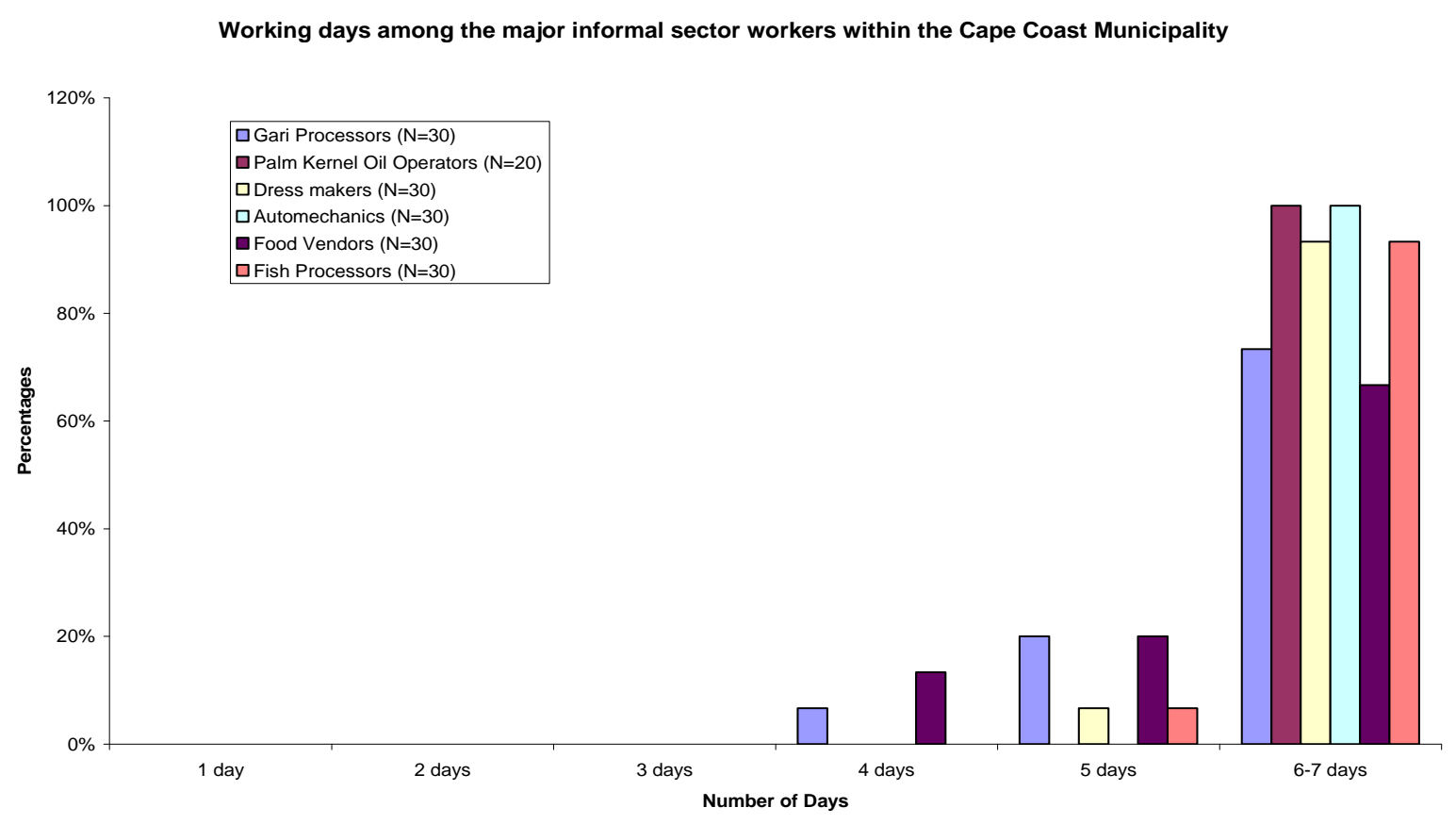

Figure 2. Working days among the major informal sector workers

\subsection{Hours of rest, working hours and working days}

In spite of the fact that they are not taken to the hospital for medical attention when injured on the job, their working hours are not reduced and they work between 6 - 7 days each week. This is also confirmed by an ILO report which states that 'the consequences of working in the informal sector are often 'long working hours with low and irregular incomes' (ILO, 2000). The working days per week of the major groups of informal sector enterprises interviewed are represented in Figure 2 and the working hours in Figure 3.

On the issue of hours of rest, $53.6 \%$ of the gari processors recorded less than an hour of rest on the job. It can be deduced that there is an intensive use of labour within this enterprise. Employees were being used extensively, working in excess of 5 days and as long as 10-hours; and no leave periods given. Only $7.4 \%$ of the gari processors were allowed to take 'Christmas leave' with no Easter leave given. Comparatively, among the female food vendors, as much as $88 \%$ stated that they had less than an hour of rest daily at their workplace. Similarly, none of them was given any Easter leave. The result is represented in Figure 4. 


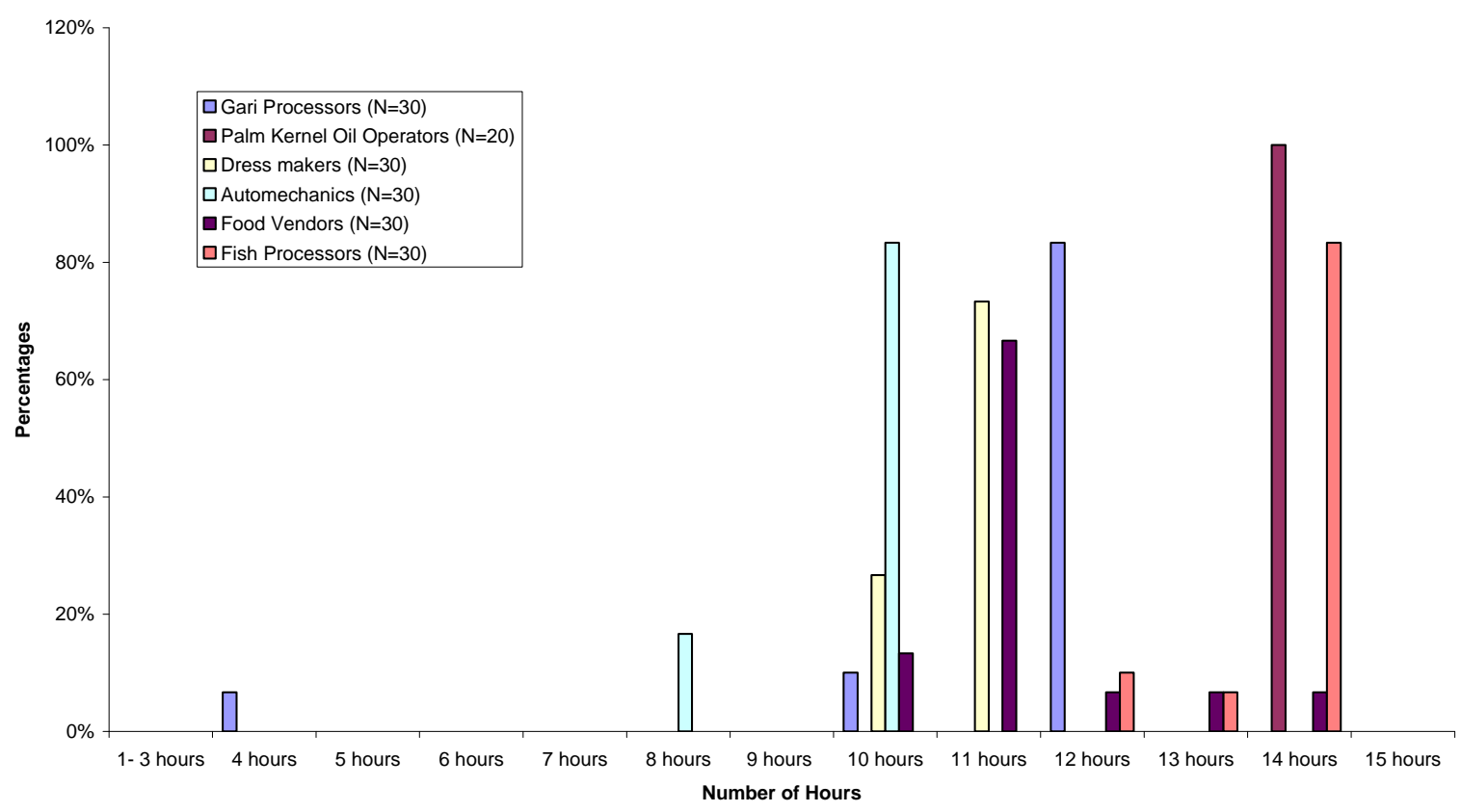

Figure 3. Working hours amongst informal sector employees within the Cape Coast Metropolis

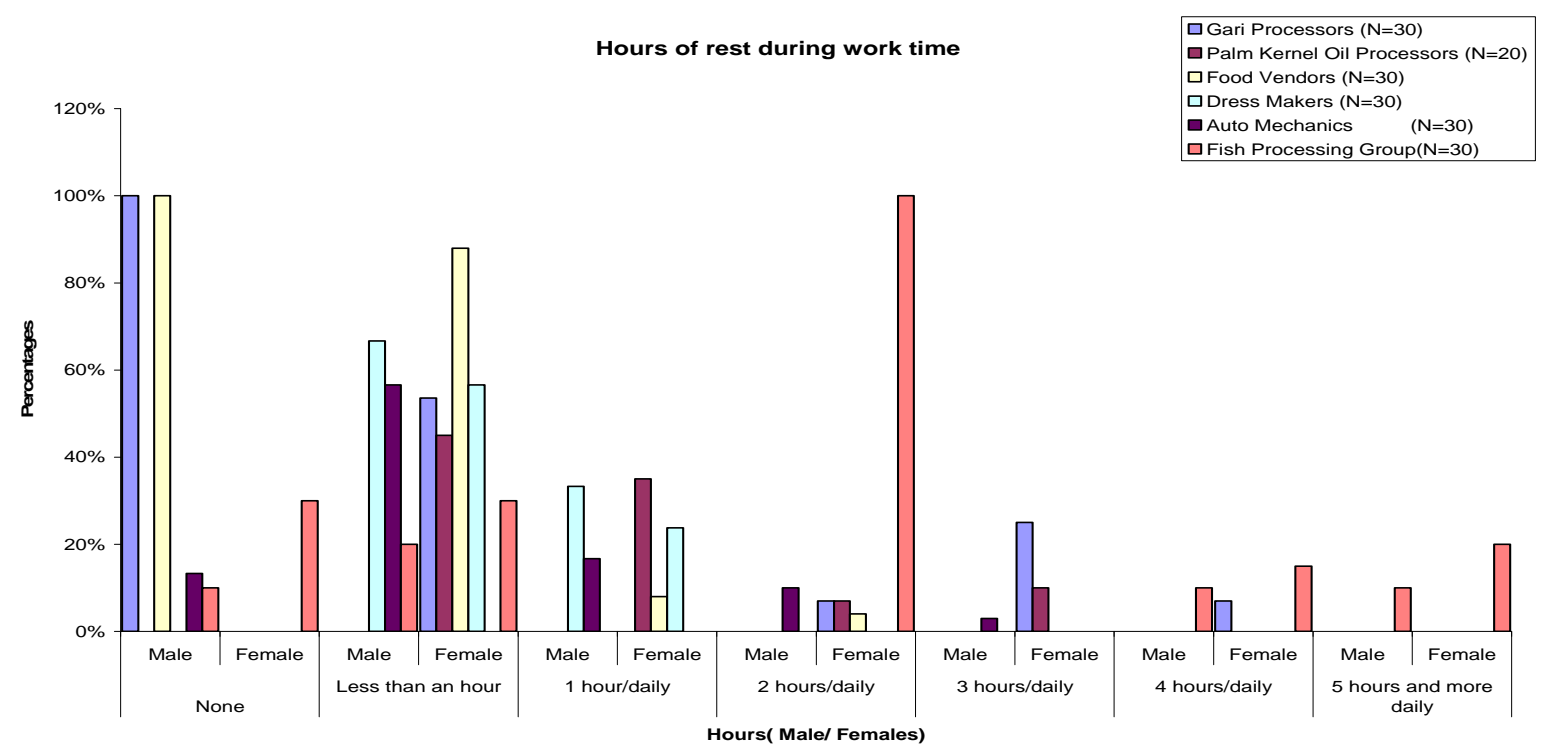

Figure 4. Hours of rest

Poor and long working hours were recorded in almost all the major groups of workers. The auto mechanics, dress makers and palm kernel oil processors recorded 56.6\%, $76.2 \%$ and $45 \%$ respectively as having less than an hour's rest on the job. No employee (apart from the senior apprentices) had more than 3-hours of rest. This corroborates the findings of other 
researchers on the informal sector (Aryeetey et al, 1988; Yankson, 1992; Barwa, 1995), which attest to poor and long working hours by labour within the informal sector.

From Figure 3, only 2 gari processors worked 4-hours in a week. These two, representing only $6.6 \%$, were part-time workers who had other jobs with other institutions. As high as 83.3\% of workers from the gari processing group worked 12-hours daily for $6-7$ days each week, and the same percentage for the fish processors who, however, worked 14-hours daily. Comparatively, $83.3 \%$ of those in the auto-mechanic group worked 10-hours each week. All the 20 employees (100\%) within the palm kernel oil processing group worked 14-hours daily. Indeed, in the administration of the questionnaire, it was realised that these workers start as early as 4 a.m. each day to prepare for their processing operations. Only $16.6 \%$ of auto-mechanic employees worked regulated 8-hour week. This is reflected in the literature reviewed on working hours within informal sector enterprises. Specifically, Part IV section 33 of the Ghana Labour Act, 2003 (Act 651) suggests a 'maximum of eight hours a day and forty hours a week'. An interesting point this data revealed is that informal sector employees work almost double the number of hours that their counterparts in the formal sector work in a day for the same or less the remuneration per month. This is because 'they do not enjoy the level of protection and guaranteed level of wages that those in the formal sector do' (Aboagye \& Yankson, 1992:37).

\subsection{Motivational and De-Motivational Factors}

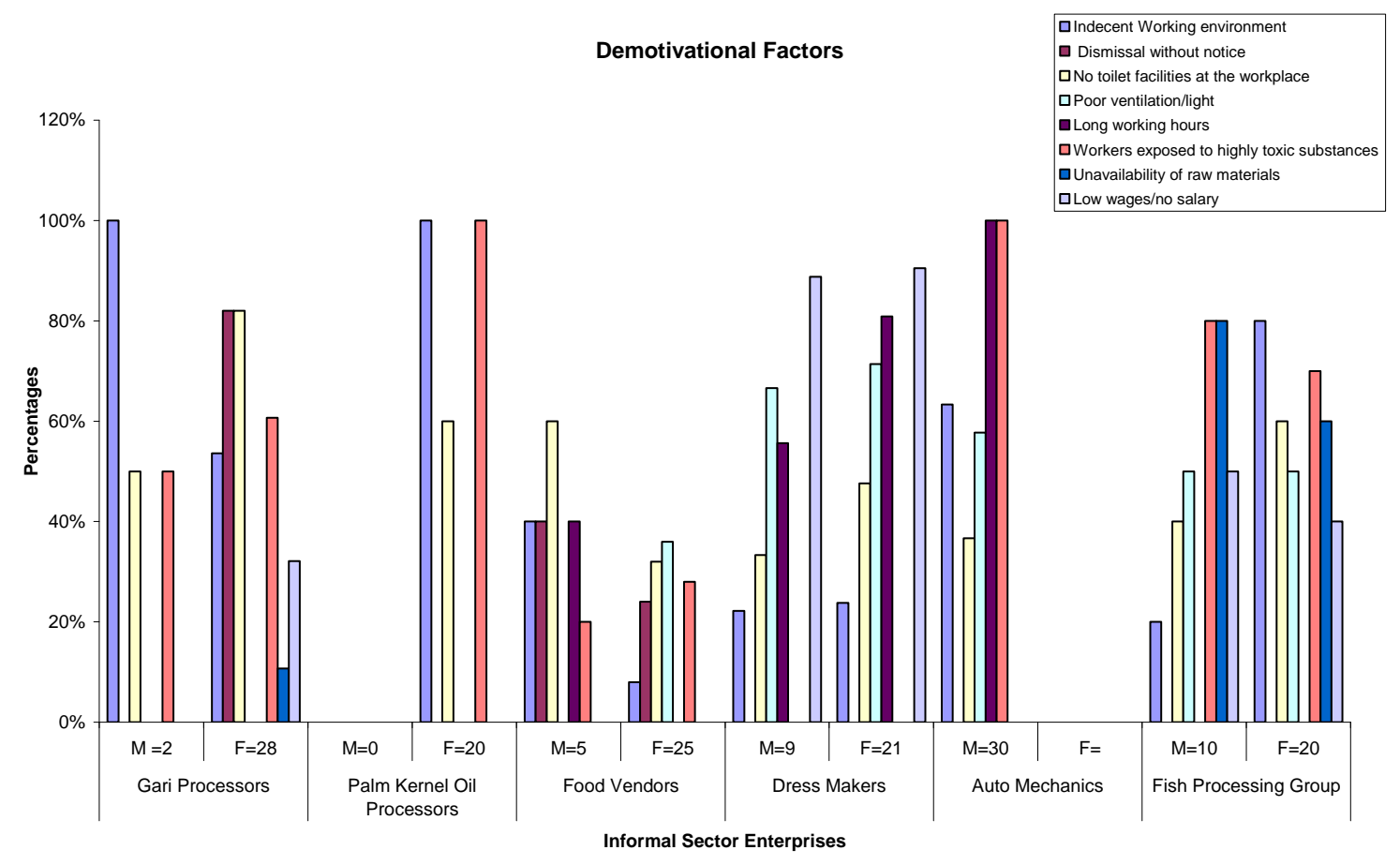

Figure 5. De-motivational factors

Major concerns were raised about motivational features and factors on the job by the employees. One of such concerns was students' vacation time on the University campus. Food vendors on the University of Cape Coast campus were granted 'some leave' during 
students' vacation time. In certain cases, some of these employees were 'asked' to stay at home because their services were not needed. In the case of the dress makers, $77.8 \%$ males and $90.5 \%$ females had to 'rest' simply because their services were not needed when the students went on holidays. This means that employees' leave days were determined solely by students' vacation period; it was not a sincere grant of period for them to take the much needed rest from the tedious work being done. This could result in de-motivating the employees. The major de-motivational factors recorded, as shown in Figure 5, included indecent working environment; dismissal without notice; no access to potable water; lack of toilet facilities at the workplace; exposure to toxic substances; and meagre wages. This situation is confirmed by the findings of Barwa's (1995) study which indicate that due to poor working conditions there is often poor access to utilities, like water and electricity. It needs to be recognised that basic facilities, such as toilet and pipe borne facilities, help to satisfy and motivate workers to give their best.

In the case of sanitary conditions at the workplace, majority of the gari processors used the nearby sea-shore as their place of convenience. Incidentally, the gari processors recorded the highest for indecent work premises - 100\% for males and $68.6 \%$ for females (Figure 5). Those in the fish processing group also recorded high figures for indecent working premises $-80 \%$ for females.

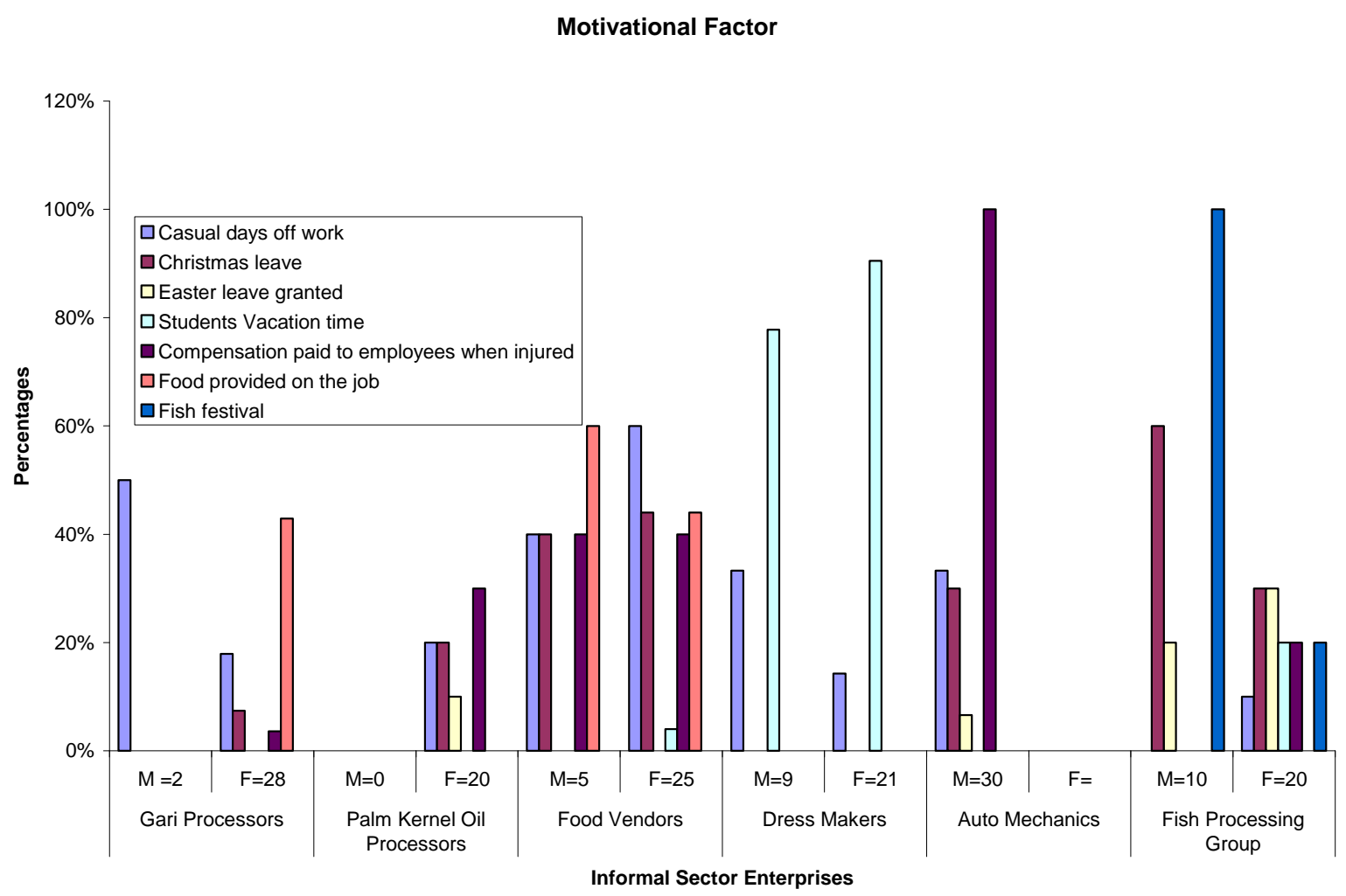

Figure 6. Motivational factors amongst the major groups of informal sector workers within the Cape Coast Metropolis 
Some existing motivational factors were: meals provided on the job; casual days; off work; and Christmas leave. These factors are represented in Figure 6. Overall, the study revealed that general working conditions were poor and highly inadequate. The absence of good working conditions, in terms of Herzberg's (1959) hygiene factors, led to dissatisfaction among the workers. This was evident amongst the workers who seemed to have resigned their fate and were not really looking for any growth opportunity; first of all because they did not have the financial strength to do so, and secondly, because they did not appear to have any inclination to break away from their current lifestyles.

\subsection{Recruitment}

The study revealed that most of the employees and/or apprentices were linked, in one way or the other, to the owners. Most of the employees were in a way related to the owner through either another relative, friend, acquaintance, and marriage. This is in agreement with the findings of other researchers on the mode of recruitment into the informal sector (e.g., Aboagye \& Yankson, 1992; Barwa, 1995; Baah-Nuakoh, 2003; Ninson 1991). There was no recruitment policy or procedure of any kind in existence. Some employees came to the Cape Coast Metropolis to assist relatives in their processing business; or came for a visit and were still helping out in the business. For the fish processing group, most of the employees got roped into helping out in the job. They remain with the relatives concerned for the rest of their working lives, assisting in the various jobs being done with no real employment opportunities for growth, and no financial security/savings to fall back on. With regard to the auto mechanics, majority of them were not related directly to the 'master' (owner) of the enterprise, but knew someone who was related to him. They were made to pay the token fee and became apprentices on the job.

The palm kernel oil processors were a small knit of family members working together. There was no interview of any sort involved. All one needed to work with the group was to be related to a member of the existing group, and proved to be hardworking. It can be deduced that, unlike the formal employment where a job comes with a job description on what tasks to perform within the job, there was nothing like this in the enterprises interviewed. Workers are made to do anything and everything on the job.

\subsection{Earnings and income}




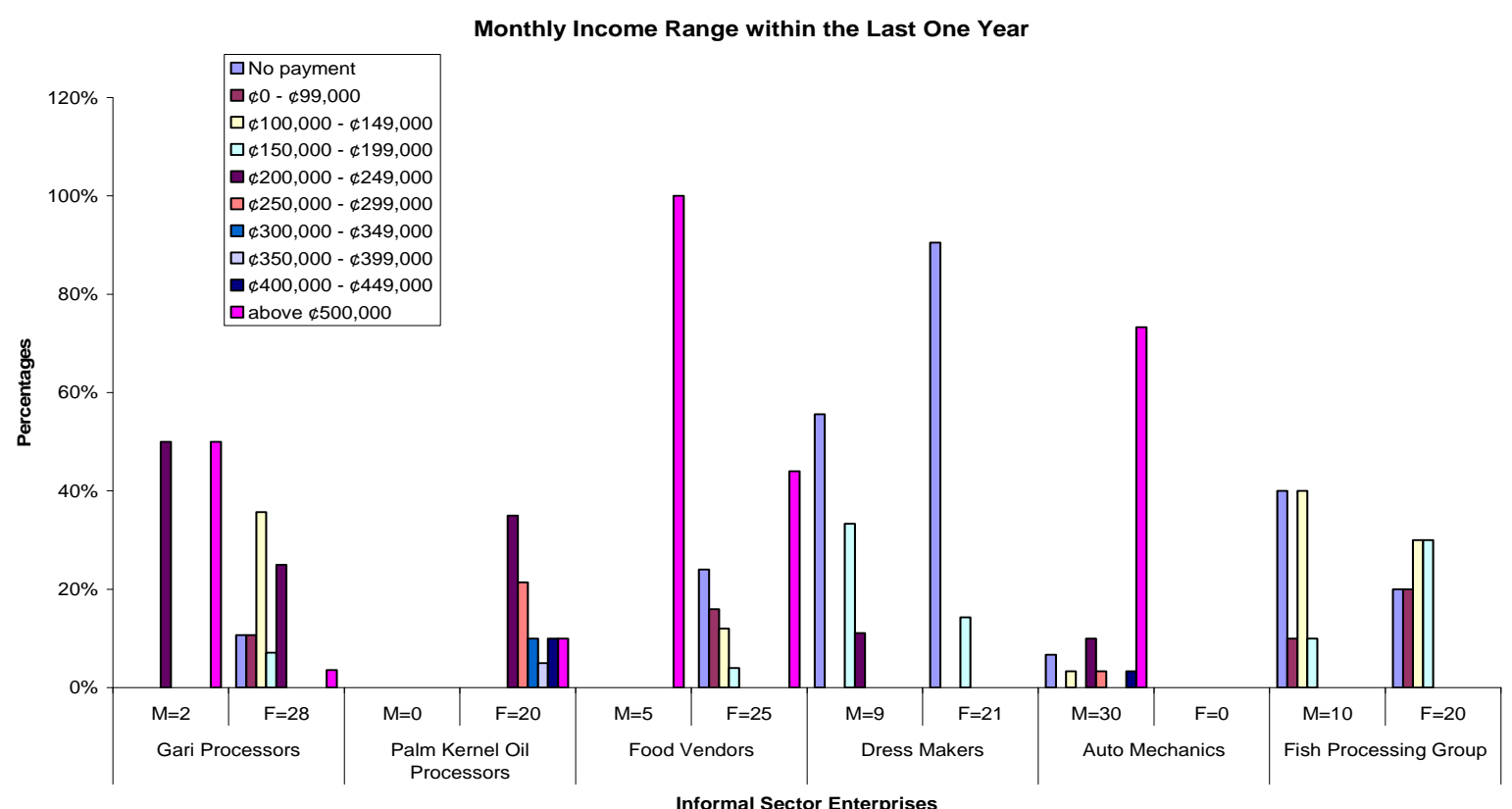

Figure 7. Monthly income range

Low wages featured prominently amongst the employees within the major groups of informal sector enterprises. In the case of the dressmakers, it was quite serious to the extent that $88.8 \%$ of males and $90.5 \%$ of females had nothing paid to them at all within any month. However, these apprentices were being used in the production of clothes for clients of their 'masters'. The masters claimed that apprentices could not be paid or earn wages. This confirms the findings of Aryeetey et al's (1988) work in the Techiman District of the Brong Ahafo Region of the country, which showed that apprentices were being used by their masters for as long as 5 years without being paid. Comparatively, $50 \%$ of those in the gari processing business also did not receive any monthly salary because most of them were working with their parents, and their services were being offered free of charge.

For those who were paid, the monthly pay of the workers was very meagre, with an average of $\$ 250000.00$ (\$16.66). From Figure 7, out of the total number of workers interviewed, $1000 \%$ received monthly wages/income of less than $\$ 500000.00$ (\$33.33) with a greater proportion of workers having their income falling between the range of $\$ 200000.00-\$ 249$ 000.00 (\$13.33 - \$16.60). This makes the real income purchasing power of all the employees very low, leading to a low level standard of living. Consequently, a greater proportion of these workers had their incomes well below the minimum daily wage of $\$ 13500.00$ (\$1.00) being paid to workers in government and parastatal agencies. This confirmed the fact that informal sector workers work much harder and earn very low incomes than their counterparts in the formal sector enterprises (Aboagye \& Yankson, 1992:37). According to the ILO's publication on decent work, earnings within the informal sector are very low, resulting in workers finding it difficult to save for periods of illness or injury (ILO, 2003). The low incomes and high working hours corroborates findings of Aryeetey et al's (1988) work which showed that excessively low wages were paid for labour within the sector. 


\subsection{Provision of Meals}

Figure 6 shows the availability of meals on the job. Only 4\% of all the employees interviewed were given breakfast (except for the fish processing group who was given some meal in the morning). Ninety percent and $80 \%$ of males and females respectively in the fish processing group were provided with breakfast. With the provision of lunch, the proportion of workers being fed on the job increased amongst the food vendors. It could therefore be concluded that in the food vending business the provision of lunch was quite adequate. This could be due to the fact that patronage of their services peaked during the lunch period. What the researchers could not ascertain, however, was whether or not the employees were given their own meals or were made to take only the leftover meal. In his study on the provision of meals and eating places at the work premises, Wanjek (2005) states that workers who were given meals on the job did not actually have balance meals, or eat what they would actually prefer, but what was available on the job. Among the auto mechanics, dressmakers and palm kernel oil processors, there was no provision of meals at the workplace. On the average, 50\% of employees working in informal enterprises within the Metropolis did not have access to potable water. They had to leave their work premises to buy water either from other shops nearby or from street hawkers. This also confirms the evidence of other research work done within informal sector enterprises (e.g., Barwa, 1995), that there is sometimes little or no access to potable water.

\subsection{Use of Child Labour}

Although the study did not specifically focus on child labour within informal sector enterprises, this issue came to light during the interview and administration of questionnaire. The use of children in the production process was very evident amongst the gari processors, food vendors, auto mechanics and dressmakers. There were young children who had just completed Junior Secondary School. In the case of the gari processors, young children who were barely four or five years old were involved in the process of steaming cassava dough. As represented in Figure 8, the fish processing group registered 23.3\% for males and 53.3\% female adolescents between the ages of 12 and 19 years involved in the trade. In the food vending business, $50.3 \%$ was recorded and $29.3 \%$ with the auto-mechanics. 
Use of Child Labour within the Informal Sector enterprises

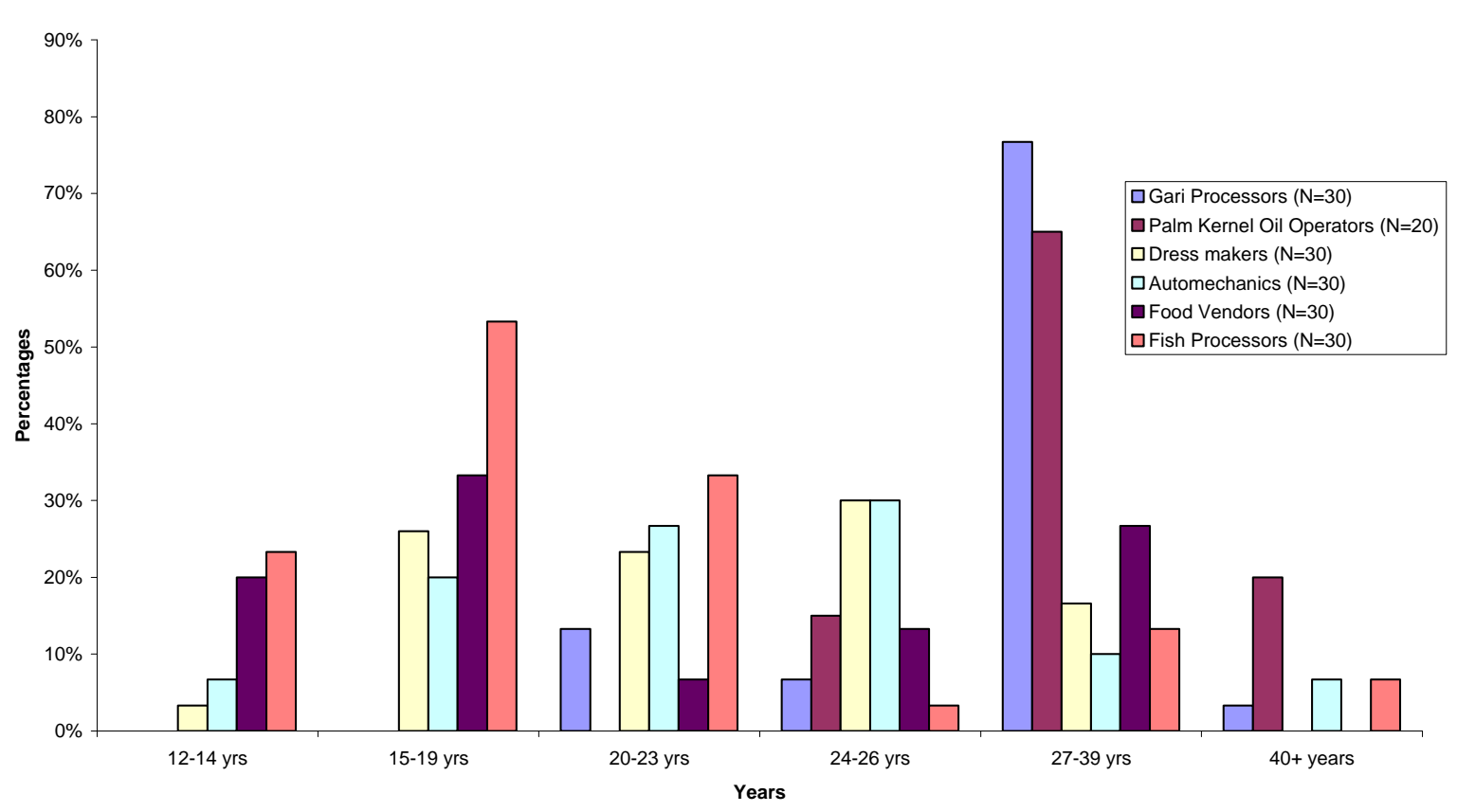

Figure 8. Use of child labour in the major informal sector groups within the Cape Coast Metropolis

One may argue that in Africa and other less developed countries, poverty levels calls for assistance from every family member to help in providing for the family. However, these young children are the future leaders of the country and, in the first instance, need to be well educated and cared for to take up their rightful positions in society. Sitting by the naked fire and smoke for more than 4-hours a day does not create the right atmosphere for such children to study and develop themselves for the future. Within the auto mechanics section of the informal sector, young children were seen learning to jump start dilapidated cars. Usually, these children are initially assigned light jobs and later some other mechanical jobs. Invariably they end up being auto mechanics without any proper training for skill acquisition.

\subsection{Training}

Contrary to expectation and what the extant literature suggests about active training and support within the informal sector, this was missing in the sector in the Cape Coast Metropolis. None of the enterprises surveyed had received any help or assistance in the form training from any non-governmental organisation (NGO), developmental agency or the government. What this means is that the knowledge which these firms have acquired informally through others over the years is what was being used. There is no infusion of any new knowledge or ideas from any recognised source to help develop them further. Consequently, the employees do not have any dream of career development, skill improvement and career advancement. They are steeped in their old ways of doing things. The employees are therefore dependent on what the 'masters' know and are willing to pass down to them. This, according to Baah-Nuakoh (2003:83), causes 'in-breeding' and is a 
major limitation of the process of skill transmission within the sector. In practice, employees' motivation to learn in training activities can also be influenced by the degree to which they have basic skills - cognitive ability, and reading and writing skills - needed to understand the content of training programmes (Noe et al., 2000).

\subsection{Employee dismissals}

Apart from the dressmakers and auto mechanics who indicated that they were given notice before being dismissed or their apprenticeship terminated, the rest of the workers interviewed stated that no notice was given before dismissal. Amongst the fish and gari processing groups, the employees indicated that if the owner of the firm was not happy with their work, it would be better to advise one's self and leave the job voluntarily. This is because the disaffected owner could sack an employee instantly against expectation. This situation is represented by $82 \%$ and $73 \%$ respectively for the females within the gari and fish processing groups (Table 1). It is quite interesting to note that, apart from the male food vendors who registered $24 \%$, none of the males within the various enterprises had an issue with rampant dismissal.

Table 1. Dismissal without notice

\begin{tabular}{|c|c|c|c|c|c|}
\hline Gari & Palm Kernel & Food Vendors & Dress Makers & Auto-Mechanics & Fish \\
\hline Processors & Oil Processors & & & (Males) & Processing \\
\hline (Females) & (Females) & & & & Group \\
\hline \multirow[t]{2}{*}{$82 \%$} & $0 \%$ & Male= $=40 \%$ & Male $=0 \%$ & $0 \%$ & Males $=0 \%$ \\
\hline & & Female $=24 \%$ & Female $=0 \%$ & & Females $=73 \%$ \\
\hline
\end{tabular}

Source: Fieldwork

\subsection{Illiteracy rates amongst informal sector workers}

Another feature which came up in the study was illiteracy rates amongst the workers. Figures recorded were very high - 35\% of employees had no formal education at all with the majority being found within the palm kernel oil processors. Within the other groups, the number of employees with basic school education was quite high, $80 \%$. The details are shown in Figure

9. The question which readily comes to mind is: What sort of future does the country have with such a high percentage of semi-literates to steer the affairs of the economy? Although no figures are readily available to support the assumption, it could be easily determined that members of this group who constitute the youth of society are numerous. 


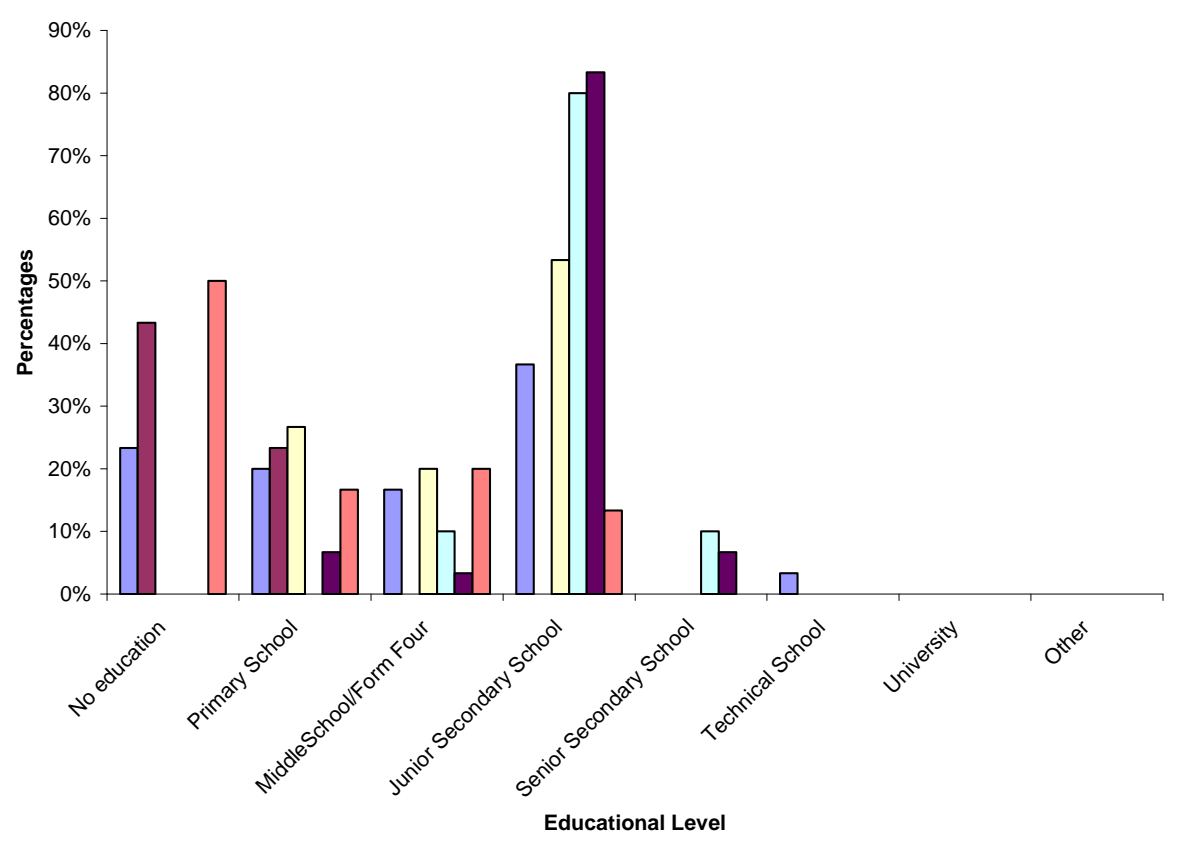

Figure 9. Illiteracy rates among the major groups of informal sector enterprises within the Cape Coast Metropolis

\subsection{Maternity leave}

The research evidence attests to the fact that informal workers, especially women and children, are at the receiving end of often dangerous and precarious work conditions. This was clearly manifested in the current study, as shown in Table 2. The women did not have anything close to maternity leave. In the case of the apprentice dressmakers, they were actually forbidden to get pregnant in course of their training. Their apprenticeship was immediately terminated if any sign of pregnancy was detected by the master. Concerning the food vendors, even though they were not forbidden to get pregnant, yet they were not expected to conceive because it would interfere with their work.

With the other groups of employees, they were allowed to get pregnant. However, as one woman stated, "When you have no money and the fish is available you will want to come to work to get some money [for both yourself and your baby]". The women within the fish, palm kernel oil and gari processing groups indicated that they were given only few weeks' off duty after birth, and they had to return to work immediately afterwards. It was not because they were enthusiastic with their work, but because it provided some income for them and their family. Within the fish processing group, some women returned to work 2 weeks after delivery. They actually came to work with their new-born babies. 
Table 2 Pregnancy/maternity leave among females in the Informal Sector

\begin{tabular}{|c|c|c|c|c|c|c|c|c|c|c|c|c|}
\hline \multirow[b]{3}{*}{ No maternity } & \multicolumn{2}{|c|}{$\begin{array}{c}\text { Gari } \\
\text { Processors }\end{array}$} & \multicolumn{2}{|c|}{$\begin{array}{l}\text { Palm Kernel } \\
\text { Oil Processors }\end{array}$} & \multicolumn{2}{|c|}{ Food Vendors } & \multicolumn{2}{|c|}{ Dress Makers } & \multicolumn{2}{|c|}{$\begin{array}{c}\text { Auto } \\
\text { Mechanics }\end{array}$} & \multicolumn{2}{|c|}{$\begin{array}{c}\text { Fish } \\
\text { Processing } \\
\text { Group }\end{array}$} \\
\hline & $M=2$ & $\mathrm{~F}=28$ & $\mathrm{M}=0$ & $\mathrm{~F}=20$ & $M=5$ & $\mathrm{~F}=25$ & $\mathrm{M}=9$ & $\mathrm{~F}=21$ & $\mathrm{M}=30$ & $\mathrm{~F}=0$ & $\mathrm{M}=10$ & $\mathrm{~F}=20$ \\
\hline & N/A & 20 & N/A & 8 & N/A & 20 & 9 & 21 & N/A & & N/A & 16 \\
\hline $\begin{array}{l}\text { Maternity } \\
\text { leave given }\end{array}$ & N/A & 8 & N/A & 12 & N/A & 5 & N/A & 0 & N/A & & N/A & 4 \\
\hline $\begin{array}{l}\text { A few days' } \\
\text { off (14 days) }\end{array}$ & N/A & 20 & N/A & 8 & N/A & 20 & N/A & N/A & N/A & & N/A & 16 \\
\hline 3 -4 weeks' off & N/A & 1 & N/A & 2 & N/A & 0 & N/A & N/A & N/A & & N/A & 1 \\
\hline $\begin{array}{c}2 \text { - } 3 \text { months } \\
\text { off }\end{array}$ & N/A & 6 & N/A & 3 & N/A & 1 & N/A & N/A & N/A & & N/A & 2 \\
\hline $\begin{array}{l}4 \text { months and } \\
\text { above }\end{array}$ & N/A & 1 & N/A & 7 & N/A & 4 & N/A & N/A & N/A & & N/A & 1 \\
\hline
\end{tabular}

Source: Fieldwork

\section{Conclusion and implications}

This study sought to assess the HR practices within the informal sector in the Cape Coast metropolis. The main objective was to determine how the human resources within the informal economy were being managed. The study sought to draw out the dimensions of HR practice and employee management within the informal economy. On the strength of the findings of the study, conclusions can be drawn that HR practices within the informal sector in the metropolis are inadequate and therefore impedes the development of the workforce, which invariably affects the growth of the enterprises. Most of the employees did not have adequate rest hours in the light of their long working hours; neither did they know that not having enough rest hinders overall productivity. Apart from the dress makers and auto mechanics, dismissal was rampant with no notice. Furthermore, the employees were not contributors to the Social Security and National Insurance Trust, and did not know about the existing National Health Insurance Scheme. With the exception of few individuals who were involved in the indigenous savings scheme ('susu'), a majority of employees within the informal sector were living from hand to mouth. The study also revealed that the promotion agencies, NGOs and other developmental agencies, contrary to expectations, were not actually working with the informal sector enterprises. These findings have important implications for management and policy makers.

The study has shown that there are some limitations with respect to managing the HR factor of the sector. None of the enterprises exists officially in any business records within the Metropolis. This is because either they are too small to be recognised or they have not registered, or they do not know that, as an enterprise, they need to be registered with officially recognised agencies, such as the National Bureau Small Scale Industries. As a first 
step, if all these 'table top' enterprises could be recognised as part of the economy-growing process and linked up with other firms, it would help to measure their contribution towards the national GDP and employment of labour. Efforts should be made to register these enterprises and their workforce, and close contact kept with them to provide assistance and monitor their work ethics. As the most important resource of the economy, it is necessary, therefore, that government's efforts to provide assistance to the informal sector be stepped up. It is recommended that the HR factor of the small scale enterprises, especially those within the informal sector - both entrepreneurs and employees - be developed to attain a certain level of expertise and education with which to help build the national economy. This can be done through training in the acquisition of skills and knowledge. It is equally important that a well articulated official policy and incentive scheme should be developed at the level of the Ministry for Manpower Planning and Development to cater for the HR needs within the informal sector. This scheme could have the following objectives: (1) Assist in stabilising employment status of persons already engaged in the sector; (2) Assist in the expansion of production and employment in existing enterprises through improved accessibility to institutional credit; (3) Improve the skill levels of the workers through specific programmes and (4) Encourage the formation of associations of informal sector enterprises or strengthen various informal sector associations to involve more informal sector activities in order to improve and strengthen their accessibility to institutional credit.

Although the study provides useful insights by demonstrating the importance of HRM practices in the informal sector, the results should be interpreted subject to the usual limitation of survey research. The main limitation of the study is that it could not cover all informal sector enterprises within the Metropolis due to time and financial constraints. This limits the extent to which the results could be generalised across other sectors and localities. On the basis of this, future research should be broad enough to cover all informal enterprises across the metropolis. Similar study should also be undertaken in other metropolis in the country for a broader perspective on HR practices.

\section{Important Notes}

1. Since this study was undertaken the Government of Ghana has implemented the Informal Savings/Pension Scheme which allows micro-enterprise owners and workers to contribute towards a Pension Fund.

2. Although not wide-spread, a number of NGOs have undertaken some small scale training in such areas as hygiene, financial management (saving plan) and the transfer of knowledge on how to improve the activities and skills within the Informal Economy.

3. The Government of Ghana in July 2007 re-denominated the Cedi (\$) to the Ghana cedi (GHS). The values stated above are therefore much lower today than what it was when the study was being undertaken.

4. The Government of Ghana has established the National Youth and Employment Sector with the sole aim of organizing the unemployed youth who have little or no formal education and specific jobs created for them. 
5. The current minimum daily wage (2011) is GHS3.73 (\$2.49).

\section{References}

Aboagye, A. A., \& Yankson, P. W. K. (1992). Employment in the urban informal sector in Ghana: Report of a survey of informal sector enterprises in Accra, Kumasi and Tema. Jobs and Skills Programme for Africa, Addis Ababa.

Acquaah-Harrison, J. B. (1990). Report on a survey of small-scale enterprises conducted in Agona Swedru District, Ghana, Accra.

Almeida, R. (2004). Does labour flexibility affect firm performance? Evidence from Brazil, World Bank and IZA Publications

Aryeetey, E. (1996). In Agenda 96 Preparing Ghana for the $21^{\text {st }}$ Century; Some economic and social issues. The Institute of Economic Affairs, Accra

Asomaning-Bimpong, L. (1991). Financing small scale industries - The role of credit institutions. Keynote address at the Opening Ceremony of the NBSSI Week Celebration. Cape Coast Town Hall, $13-19^{\text {th }}$ September

Baah-Nuakoh, A. (2003). Environment, informal sector and factor markets. Accra: Woeli Publishing Services.

Barwa, S. D. (1995). Structural adjustment programmes and the urban informal sector in Ghana. Development and Technical Cooperation Development Department, ILO, Geneva

Benería, L. (1989). The informal economy: Studies in advanced and less developed countries. A. Portes, M. Castells \& L. Benton (Ed.). Baltimore: Johns Hopkins University Press.

Cross, J. C. (1998). The informal sector. Encyclopaedia of political economy. P. O’Hara (Ed.). London: Routledge.

Del Castillo, I. Y. (1984). Precarious employment and trade unionism: Subcontracting in Peru?Gresea.Louvain-la-Neuve.

De Soto H. (1986). The other path: The invisible revolution in the third world. New York: Harper \& Row.

Drucker, P. (1982). Employing the whole man. The practice of management. New York: Harper \& Row.

Due, J. M., Darmawan, D., \& Syukur, M. (1992). Lessons for Africa from Indonesia’s experience in small scale entrepreneurial finance. African Development Review, 4(1). http://dx.doi.org/10.1111/j.1467-8268.1992.tb00148.x.

Finnegan, G. (2000). Developing the knowledge base on women entrepreneurs: Current work of the International Labour Organization in Women's Entrepreneurship Development and Gender in Enterprise. $2^{\text {nd }}$ OECD Conference on Women Entrepreneurs, Paris, November 2000. 
Ghana Publishing Corporation (2003). Labour Act, 2003 (Act 651). Government Printer, Accra

Ghana Statistical Services (2000). Ghana living standards survey. Accra

Government of the Philippines: Philippines social reform agenda. Master plan of operations, workers' protection and welfare workers, especially in the informal sector. Retrieved from http.www.ilo.org/public.

Hart J. K. (1970). Small-scale entrepreneurs in Ghana and development planning. The Journal of Development Studies. 6, 104-120. http://dx.doi.org/10.1080/00220387008421338.

Hansenne, M (1991). The dilemma of the informal sector. International Labour Conference, Geneva, ILO.

Herzberg, F. (1959). The motivation to work. Pittsburg: John Wiley \& Sons, Inc.

ILO Publications (2002). Globalization and the informal economy: How global trade and investment impact on the working poor.

International Labour Organization. (2000). Regional office for Asia and the Pacific: The informal sector. Bangkok. Retrieved from ww.ilo.org/public/english/region/asro/bangkok/feature/inf_sect.htm

ILO/JASPA. (1986). Informal sector in Africa. Addis Ababa.

ILO Publications. (2003). Decent employment through small enterprises

Justice, R. (2002). Firms and the burden of regularization in Brazil. World Bank discussion papers.

Kendie, S. B. (1998). Employment structure and the environment in Cape Coast, Ghana.

$\begin{array}{llll}\text { Singapore Journal of Tropical Geography, } 19 & \end{array}$

(1).

http://dx.doi.org/10.1111/j.1467-9493.1998.tb00248.x.

Lagos, R. (1992). Barriers to legality and their costs for the informal sector. In Tokman (Ed.) Beyond Regulation: The informal economy in Latin America. Boulder.

Musiolek, B. (2002). Decent work in the informal sector: CEE/CIS region. International Labour Office, Geneva.

Ninsin, K. A. (1991). The informal sector in Ghana's political economy. Accra: Freedom Publication.

Noe, R. A., Hollenbeck, J. R., Gerhart, B., \& Wright, P. M. (2000). Human resource management: Gaining a competitive advantage ( $3^{\text {rd }}$ ed.). New York: Irwin/McGraw-Hill.

People’s Daily Graphic (2005, 20 September). Number 149538.

Portes, A., \& Walton, J. (1981). Labour, class and the international system. New York: Academic Press. 
Salter, W.D. (2002). International OSH Programme on the Informal Sector. ILO Publications, Geneva.

Sethuraman, S. V. (1977). Employment promotion in the urban informal sector in Ghana. World Employment Research Working Paper, ILO, Geneva.

Schneider, F. (2002). Size and measurement of the informal economy in 110 countries around the World. Paper presented at a Workshop of Australian National Tax Centre, ANU, Canberra, Australia.

Shumpeter, J. A. (1961). The theory of economic development: An inquiry into profits, capital, credit, interest and business cycles. New York: Oxford University.

Smith, P. (1994). Assessing the Size of the Underground Economy. Canadian Observer Catalogue, Number 11- 0103-16-3-33.

Soares, F. V. (2004). Informal labour market in Brazil: Job queue, trade liberalization and minimum wage. (Unpublished doctoral dissertation). University College London.

Tesselaar, A. (1998). Organizing in the informal economy - the role of the trade unions. Amsterdam, FNV Mondiaal.

Thomi, W. H. \& Yankson, P. W. K. (1985). Small-scale industries and decentralization in Ghana. A preliminary report on small scale and medium- sized towns in Ghana. University of Ghana, Legon.

World Confederation of Labour (2002). Working in the Informal Sector: an opportunity, a risk, a challenge. Annual Report Brussels. Retrieved from http.www.wcl.org.

Yankson, P. W. K. (1989). Small-scale industries in the implementation of a growth centre strategy of regional development: A case study of Ghana. Industry and Development, 17.

Yankson, P. W. K. (1992). Employment in the urban informal sector in Ghana. ILO/JASPA, Addis Ababa. 